\title{
Layered Intrusions: From Petrological Paradigms to Precious Metal Repositories
}

DOI:

10.2138/gselements.13.6.383

\section{Document Version}

Accepted author manuscript

Link to publication record in Manchester Research Explorer

\section{Citation for published version (APA):}

O'Driscoll, B., \& VanTongeren, J. A. (2017). Layered Intrusions: From Petrological Paradigms to Precious Metal Repositories. ELEMENTS, 383-389. [13(6)]. https://doi.org/10.2138/gselements.13.6.383

\section{Published in:}

ELEMENTS

\section{Citing this paper}

Please note that where the full-text provided on Manchester Research Explorer is the Author Accepted Manuscript or Proof version this may differ from the final Published version. If citing, it is advised that you check and use the publisher's definitive version.

\section{General rights}

Copyright and moral rights for the publications made accessible in the Research Explorer are retained by the authors and/or other copyright owners and it is a condition of accessing publications that users recognise and abide by the legal requirements associated with these rights.

\section{Takedown policy}

If you believe that this document breaches copyright please refer to the University of Manchester's Takedown Procedures [http://man.ac.uk/04Y6Bo] or contact uml.scholarlycommunications@manchester.ac.uk providing relevant details, so we can investigate your claim.

\section{OPEN ACCESS}




\title{
Layered intrusions: From petrological paradigms to precious metal repositories
}

\author{
Brian O'Driscoll ${ }^{1}$ and Jill VanTongeren ${ }^{2}$ \\ ${ }^{1}$ School of Earth and Environmental Sciences, University of Manchester, Williamson Building, \\ Oxford Road, Manchester, M13 9PL, UK \\ ${ }^{2}$ Department of Earth and Planetary Sciences, Rutgers University, 610 Taylor Rd., Piscataway NJ \\ 08854, USA
}

\begin{abstract}
Layered mafic-ultramafic intrusions have occupied a position of central importance in the field of igneous petrology for almost a century. In addition to underpinning petrological paradigms such as cumulus theory, some layered intrusions are exceptionally enriched in base and precious metals, including the platinum-group elements. Technological advances are driving the current and future state-of-the-art in the study of layered intrusions and, looking forward, it is clear that these bodies will continue to inspire and challenge our understanding of magmatic systems and magma solidification for many years to come.
\end{abstract}

\section{WHAT ARE LAYERED INTRUSIONS AND WHERE DO WE FIND THEM?}

Layered intrusions are traditionally interpreted as the solidified remnants of basaltic magma chambers (Fig. 1A). Vertical sections through the stratigraphy of these intrusions represent a potentially powerful tool for decoding the geochemical evolution of magmas, interrogating the magma chamber filling history and understanding numerous processes operating in solidifying intrusions in the shallow crust. The characteristic layering in these bodies is usually defined by textural changes or variations in the proportions or the chemical compositions of minerals from one layer to the next. Such layering is a feature of many gabbroic and peridotitic bodies worldwide, as well as (less commonly) more compositionally evolved intrusions (e.g., Fig. 1B). Layered intrusions vary in size (e.g., several $\mathrm{km}^{2}$ to tens of thousands of $\mathrm{km}^{2}$ in areal extent), as well as shape. For example, funnel-shaped (Bushveld Complex, South Africa), box-shaped (Skaergaard Intrusion, SE Greenland), and sheet-like bodies (Great Dyke, Zimbabwe) may all develop magmatic layering.

Layered intrusions occur through almost the entirety of the geological record, from the Hadean to the Cenozoic, with little pattern or clustering evident in terms of their distribution through time. Generally, they develop in anorogenic tectonic settings, associated with large igneous provinces and significant degrees of mantle partial melting (Fig. 2). Many well-known layered intrusions fall into this category, including the Skaergaard and Bushveld intrusions. There are significant lithological variations in the rock-types that characterise different intrusions. These differences probably reflect compositional variation in the crustal rocks through which the parental magmas passed and were emplaced into, as well as the chemical composition of these melts. For example, the Muskox intrusion (Nunavut, Canada) is dominated by peridotites and pyroxenites ( 75 vol.\%) and is emplaced into an array of Palaeoproterozoic gneisses and metavolcanics. Its parental magmas are considered to have been relatively primitive (Mg-rich) mantle melts. By contrast, the Kiglapait intrusion (Labrador, Canada) is dominated by troctolite and is part of the Nain anorthosite province, with parental magmas that were basaltic in composition. Formation of the highly unusual (syenitic) Ilímaussaq intrusion is attributed to extreme degrees of fractionation of an alkali-basalt parental magma, coupled with melting of metasomatised sub-continental lithospheric mantle (Marks and Markl 2015).

The spectrum of layered intrusions preserved in the geological record thus appears to indicate that significant differences in the chemical composition of magma and also in the size of 
the magmatic system do not matter much when it comes to the processes that are responsible for layering. The Rum Layered Suite is 2 orders of magnitude smaller than the Bushveld Complex, yet both preserve layering at similar (centimetre-to-metre) scales (see Fig. 3).

It has been suggested that layered intrusions may not be restricted to Earth. Based on wholerock compositions collected by the Mars Spirit rover, the Columbia Hills region of the Gusev crater has recently been suggested to contain a layered intrusion that contains harzburgites, olivine norites, gabbronorites and apatite-bearing leucocratic norites (Francis 2011). In addition to the implications for expanding our understanding of magmatic systems to extraterrestrial settings, these observations may eventually have implications for mineral resource considerations and exploitation.

\section{HISTORY AND RELEVANCE OF LAYERED INTRUSIONS TO IGNEOUS PETROLOGY}

Although there are many mafic intrusive bodies found on Earth, there are comparatively few 'exceptional' layered intrusions exposed today. These few intrusions, including (but not restricted to) the Skaergaard Intrusion, the Bushveld Complex, the Great Dyke, the Kiglapait Intrusion, the Stillwater Complex (North America) and the Rum Layered Suite (Scotland), have represented natural laboratories for studying magmatic processes for more than a century and lie at the heart of fundamental and classic petrological theories of magmatic differentiation.

Initial scientific interest in layered intrusions kindled in the early-mid 1900s following the recognition that they sometimes host economic base and precious metal mineralisation, including platinum-group element (PGE) deposits. Since then, significant advances have been made in understanding the dynamic, thermal and chemical consequences of magmatic processes that are evidenced in these bodies. Accordingly, the scientific literature on layered intrusions encompasses an extraordinary array of geochemical, geophysical, fluid dynamic, numerical, petrographic and field-based studies.

As we write, we approach the $50^{\text {th }}$ anniversary of one of the most important published works in the subject of igneous petrology (Wager and Brown 1968). In this superlative text, Lawrence R. Wager and G. Malcolm Brown brought together almost 40 years of research and ideas on the formation of layered intrusions. Wager's earliest post-PhD work (in western Ireland) was interrupted when he was appointed geologist on the British Arctic Air-Route Expedition in 193031. His first glimpse of the iconic Skaergaard intrusion in East Greenland was from the sea on one of those expeditions, and there is anecdotal evidence that at the time he considered the layered gabbros to be a succession of Devonian red beds. Wager would go on to spend most of his career studying the Skaergaard, as well as accomplishing remarkable achievements in mountaineering and exploration, photo-reconnaissance, and becoming Professor of Mineralogy and Geology at Oxford University along the way, before his untimely death in 1965.

The fundamental principle underpinning the ideas proposed by Wager and Brown (1968) is cumulus theory (see also Wager et al. 1960). Gravity-driven crystal settling, leading to accumulation of crystals on a substrate, was invoked to explain many of the textures (and geochemical trends) observed in layered intrusions. This is a simple and elegant model and, on the face of it, does a very good job of explaining the textures of layered cumulates. Cumulus crystals typically form a framework, the interstices of which are filled with intercumulus minerals that crystallised at the postcumulus stage (Fig. 4). The proportion of intercumulus material is used to differentiate between adcumulates, mesocumulates and orthocumulates (see Table 1 for glossary of terms), each reflecting different degrees of 'communication' between the mushy solidifying cumulate and the magma column above. Many layered intrusions preserve spectacular structures that suggest sedimentary-style deposition, lending further support to the crystal settling model and cumulus theory. These include cross-bedding, scour structures and dropstones.

A revolution came in the 1970s, with the publication of proposals that many of the features of layered intrusions could form in situ, in boundary layers at the interface between magma and solid cumulate, around the edges of the magma body (e.g. Campbell 1978; McBirney and Noyes 
1979). Soon after, the recognition of postcumulus modification of primary cumulus textures (and geochemistry) raised the prospect that the textures of some layered cumulates might form after accumulation (e.g. Sparks et al. 1985). Subsequent decades have witnessed the tides of debate ebb and flow, with arguably the central question concerning the degree to which layered cumulates may be used to extract information about the magma and the crystals that accumulate from it. Over the past 30 years, there have been strong arguments from some workers that certain features of layered intrusions, including some types of layering, are formed through metasomatic or recrystallisation processes (e.g. Boudreau 1995; Fig. 5A), meaning that some cumulates might have more in common with metamorphic, rather than igneous, rocks. Coming full circle in 1998, a landmark publication Neil Irvine and co-workers robustly defended aspects of the magmatic sedimentation model, and demonstrated that not all of the features of the Skaergaard layered cumulates could be formed by in situ crystallisation.

Debate over how the magma chambers that produce layered intrusions evolve and differentiate has been ongoing since the early work of Bowen (1928). Bowen argued that mafic magmas must evolve to produce silica-rich magmas, such as granites; whereas Fenner (1929) suggested that the Fe-rich compositions observed in magnetite and ilmenite grains near the tops of layered intrusions such as the Skaergaard and Bushveld Complexes required that the magma evolve toward an Fe-rich end member. As Holness et al. (this issue) point out, this debate is still ongoing. Nevertheless, the near-ubiquitous observation of increasingly Fe-rich and Si-rich cumulate compositions with increasing stratigraphic height in the layered series' of layered intrusions has been the hallmark of igneous differentiation and fractional crystallization theories. The observations of changes in mineral chemistry and phase assemblage (e.g., compositional evolution of the magma to crystallise fayalitic, instead of forsteritic olivine) in layered intrusions have been reproduced in the laboratory by fractional crystallization experiments.

Today, layered intrusions remain objects of fascination for petrologists. On the one hand, application of the correct techniques has the potential to reveal a wealth of knowledge about the crystallisation of magma. Balanced against this are the unknown degrees of textural and geochemical modification that layered cumulates may have undergone. We know that such postcumulus effects occur, and there are many examples of cumulate texture that defy straightforward explanation (Figs. 5A, 5B), meaning that a healthy degree of caution is required when interpreting cumulate textures. Thus, to some extent we are trapped by the genetic connotations implicit in cumulus theory terminology; the simple subdivision of cumulus and intercumulus components in a solidified cumulate don't properly account for the full complexity of processes that may occur in layered intrusions.

\section{LAYERED INTRUSIONS AS PRECIOUS AND BASE METAL REPOSITORIES}

Layered intrusions are of significant economic importance. Processes including magma mixing and magma chamber replenishment, magma-crust interaction and hydrothermal alteration are all known to concentrate valuable metals. The formation of ore deposits by these mechanisms is exemplified in layered intrusions. Maier and Hanski (this issue) provide an account of the way that tectonic setting and volume of magma has controlled the metal inventory of an array of layered intrusions in northeastern Fennoscandia. The Bushveld, Stillwater and Great Dyke intrusions have world-class economic platinum-group element (PGE) deposits. In particular, the three ore deposits of the Bushveld intrusion (Merensky Reef, UG-2 chromitite and the Platreef) provide $\sim 75 \%$ of globally exploited platinum, $\sim 35 \%$ of the world's Pd, and $>80 \%$ of its Rh (Mungall and Naldrett 2008). The PGE are commonly associated with chromitite in layered intrusions (Fig. 6), which has led to chromitite formation and PGE concentration being linked in many petrogenetic models, although there is still active debate (Mathez and Kinzler, this issue).

In the case of the Bushveld, as well as the Great Dyke and Stillwater intrusions, there is a compelling case for open system behaviour, i.e., replenishments of new magma, bringing about the 
formation of the chromitite, if not the PGE concentrations. However, the relatively recently discovered Platinova reef of the Skaergaard intrusion suggests that such open system behaviour is not required (Holness et al. this issue) for precious metal enrichment. Although models are still being developed for the formation of the Platinova reef, an interesting observation is that the mineral assemblage hosting the PGE may have equilibrated at temperatures as low as $\sim 300^{\circ} \mathrm{C}$ (Karup-Møller et al. 2008), significantly extending downwards the temperature range that layered intrusion processes are traditionally envisaged to occur within.

Base metal $(\mathrm{V}, \mathrm{Ni}, \mathrm{Cr})$ mineralisation in layered intrusions can also be significant. For example, the Bushveld hosts $\sim 15 \%$ of the world's Ni reserves (Naldrett 2004), as well as significant $\mathrm{V}$ and $\mathrm{Ti}$ in the magnetitite layers of the Upper Zone (estimated at $\sim 25 \%$ and $>30 \%$ of the world's reserves, respectively; Naldrett 2004). The Mesoproterozoic Ilímaussaq intrusion of southern Greenland is considered to be the second largest repository of REE on Earth, and the sixth largest U deposit, making it an attractive prospect for industry against a backdrop of ever-increasing global demand for these high-value commodities. The Ilímaussaq parental melts are considered to have evolved with their alkalis and halogens retained in solution, but it is the transition from magmatic to hydrothermal behaviour in the system and the ability of late-stage fluids to carry the REE and other elements of economic interest that seem pivotal in understanding the development of the ore deposit (Marks and Markl 2015).

\section{CURRENT CONTOVERSIES AND NEW DEVELOPMENTS}

Despite the knowledge we have gained from a great breadth and depth of work on layered intrusions, the formation of layering, cumulate textures and geochemical trends in these bodies are still debated. Fundamental disputes persist concerning the very nature of magmatic differentiation and what is required to make a layered intrusion (cf. Latypov et al. 2015). The principle challenge is that, although layered intrusions frequently preserve outstanding evidence for an array of dynamic and diverse petrological processes, this is only indirect evidence of the evolution of the parental magma(s), of which they are the solidified products. Ultimately, further enhancing our understanding of layered intrusions will yield new insights into magma differentiation trends, the rheological behaviour of crystal mushes, as well as the timescales over which substantial crust forming episodes occur.

Modern analytical advancements are repeatedly challenging the paradigm of cumulus theory, and even the notion that all layered intrusions represent solidified magma chambers. For example, increased precision in geochronological techniques has recently revealed exciting new information. $\mathrm{U}-\mathrm{Pb}$ dating of chromitite-hosted zircon suggests that some units in the middle of the Bushveld intrusion stratigraphy are younger than those above (Mungall et al. 2016). This means that the layered sequence is not in stratigraphic order, and thus cannot have been constructed from the bottom up. This new finding takes on even greater significance when it is considered that the purportedly intrusive bodies are also those associated with PGE-enrichment. Effectively, it means that the Bushveld intrusion may have been built incrementally, as a sill complex. This is not a new idea, as it was suggested for the Rum layered intrusion as early as 1908 by Alfred Harker, and also by Jean Bédard and colleagues (1988), and most recently revisited by Hepworth et al. (2017). If this exciting new avenue holds up to further scrutiny and investigation and multiple layered intrusions are shown to contain 'out-of-sequence' layering, it will be a profound development not just in layered intrusion research, but in igneous petrology and the geological sciences more generally.

The development and application of in situ microbeam and sample extraction techniques are also revealing new insights into crystal scale textural and compositional disequilibrium in cumulates. Morse et al. (this issue) describe the broad utility of compositional zonation in plagioclase as a recorder of magma chamber processes. In addition to major and trace element zoning, cumulus plagioclase from the Rum intrusion preserves intra-crystal isotopic zoning $\left({ }^{87} \mathrm{Sr} /{ }^{86} \mathrm{Sr}\right.$ ), an observation that has also been made for the Bushveld Complex (Morse et al. this 
issue, and references therein), underlining the importance of crustal contamination in the magma bodies and the growth of plagioclase from isotopically distinct melts. In situ LA-MC-ICPMS has been used to show that the platinum-group mineral assemblage in the Merensky Reef may have experienced a late-stage hydrothermal overprint with respect to the ${ }^{190} \mathrm{Pt} /{ }^{186} \mathrm{Os}$ system $(\mathrm{Coggon}$ et al. 2012). There are significant implications here for the ability of late stage hydrothermal fluids to refine and upgrade precious metal ore deposits.

A major innovation over the past decade has paradoxically come through the application of technology that has been available for $>100$ years. The work of Marian Holness (Holness et al. 2012) and colleagues is based on the use of a universal stage mounted on an optical microscope to measure 'true' (3D) dihedral angle populations at three-grain junctions, and has been applied to Rum and Skaergaard in particular. Holness et al. (2012; and references therein) argue that the dihedral angle yields information on the cooling rate of cumulates. In the closed system Skaergaard intrusion, dihedral angle data have been used to draw conclusions on the timing of arrival of new phases on the magma liquidus and the thermal budget of the intrusion as a whole. This groundbreaking work has not gone unchallenged (e.g. McBirney et al. 2007), but has opened up a new approach for workers to study other layered intrusions and is stimulating new questions about the sorts of information that can be extracted from cumulates.

The application of other quantitative textural techniques to layered intrusions is also flourishing. Crystal size distributions and methods of quantifying crystal alignment such as electron backscatter diffraction (EBSD) and anisotropy of magnetic susceptibility (AMS; O'Driscoll et al. 2015) are examples of such investigative tools. The power of these techniques, especially when combined, as well as their potential to future research is illustrated in the article by Cheadle and Gee (this issue). However, the combined AMS and EBSD dataset from the Dufek intrusion (Antarctica) described by Cheadle and Gee also underlines the complexity of textural evolution and fabric development in crystal mushes. As a final example of how technology is facilitating real progress in the visualisation and quantification of layered intrusion microstructures (e.g., PGE ore deposit textures), it also worth highlighting X-ray computed tomography (CT) as a novel and groundbreaking technique (Fig. 6). X-ray CT scanning allows a whole range of qualitative and quantitative analyses to be carried out on phases of interest.

\section{FUTURE OUTLOOK AND AIMS OF THIS ISSUE}

The aim of this issue of Elements is to offer a snapshot of the state-of-the art in layered intrusion research, and take a look forward at new directions of investigation in the field. The articles that follow this introduction balance the historical perspectives of nearly 100 years of research with the current frontiers in layered intrusion study, bringing together perspectives on some of the active debates and information from new geochemical and textural techniques being applied to cumulates. Looking forward, research on layered intrusions is in a very dynamic state and is being carried out by different groups all over the world. This was evidenced at a recent GSA Penrose conference held on the Stillwater intrusion (August 2016). An important outcome of this meeting was the collective definition, by $>50$ layered intrusion petrologists, of several key outstanding questions in the field (Boudreau et al. 2016). It is perhaps fitting to end this introduction by sharing those questions, as follows:

- What are the timescales of emplacement and cooling of layered intrusions?

- What is the physical nature of a magma chamber?

- Have large volume mafic magma chambers ever existed?

- How do monomineralic layers form in layered intrusions?

- How much crustal contamination occurs in layered intrusion magmatism?

- In what tectonic settings are layered intrusions likely to form?

- What can we learn from the material sciences about the cooling and solidification of layered cumulates? 


\section{DIRECTIONS FOR FURTHER INFORMATION}

Many of the new techniques that are being exploited in layered intrusion research, as well as detailed up-to-date reviews of the geology and petrology of several well-known intrusions (e.g. the Bushveld, Kiglapait and Sept Iles bodies) are described in the recently (2015) published textbook, entitled 'Layered Intrusions', edited by B. Charlier, O Namur, R Latypov and C Tegner. There is a well-illustrated chapter detailing the formation of different types of igneous layering. This text builds, in part, on the shoulders of two earlier compilations, one edited by Ian Parsons, called 'Origins of Igneous Layering' (1987) and the other by Grant Cawthorn called 'Layered Intrusions' (1996). Each of the latter two books contains a wealth of classic work on layered intrusion petrology.

\section{ACKNOWLEDGEMENTS}

Michael Marks and Belinda Godel are thanked for their permission to reproduce the photographs in Figures 1 and 6, respectively. The British Geological Survey is thanked for its permission to use the image in Figure 1a, which is reproduced from Emeleus, $\mathrm{CH}$ and Bell, BR. (2005). British regional geology: The Palaeogene volcanic districts of Scotland. $4^{\text {th }}$ Edition, Keyworth, Nottingham: British Geological Survey (permit number CP17/061). Comments on earlier drafts of the manuscript by Marian Holness, Wolf Maier and Ed Mathez are gratefully acknowledged, as is the thoughtful and constructive review by the Principal Editor, Friedhelm Van Blanckenburg.

\section{REFERENCES}

Bédard JH, Sparks RSJ, Renner R, Cheadle MJ, Hallworth MA (1988) Peridotite sills and metasomatic gabbros in the Eastern Layered Series of the Rhum Complex. Journal of the Geological Society, London 145: 207-224

Boudreau AE (1995) Crystal aging and the formation of fine-scale layering. Mineralogy and Petrology 54: 55-69

Boudreau AE, Ferré EC, O’Driscoll B, Ripley EM (2016) Layered Mafic Intrusions and Associated Economic Deposits. Penrose Conference Report, GSA Today November: 25-26

Bowen, NL (1928) The evolution of the igneous rocks. Princeton University Press, Princeton, New Jersey, 334 pp.

Campbell IH (1978) Some problems with cumulus theory. Lithos 11: 311-323

Cawthorn RG (ed) (1996) Layered Intrusions. Developments in Petrology 15: pp 530

*Cheadle MJ, Gee JS (2017) Quantitative textural insights into the construction and architecture of layered intrusions. Elements (this issue)

Coggon JA, Nowell GM, Pearson DG, Oberthür T, Lorand J-P, Melcher F, Parman SW (2012) The

${ }^{190} \mathrm{Pt}-{ }^{186}$ Os decay system applied to dating platinum-group element mineralization of the Bushveld Complex, South Africa. Chemical Geology 302-303: 48-60

Fenner, CN (1929) The crystallization of basalts. American Journal of Science 18, 225-253. 
Francis D (2011) Columbia Hills - An exhumed layered igneous intrusion on Mars? Earth and Planetary Science Letters 310: 59-64

Hepworth L, O’Driscoll B, Gertisser R, Daly JS, Emeleus CH (2017) Incremental construction of the Unit 10 peridotite, Rum Eastern Layered Intrusion, NW Scotland. Journal of Petrology, 58(1), 137-166.

Holness MB, Humphreys MCS, Sides R, Helz RT, Tegner C (2012) Toward an understanding of disequilibrium dihedral angles in mafic rocks. Journal of Geophysical Research 117 B06207: doi:10.1029/2011JB008902

*Holness MB, Nielsen TFD, Tegner C (2017) The Skaergaard intrusion of East Greenland: a natural laboratory for igneous petrology? Elements (this issue)

Irvine TN, Anderson JC, Brooks CK (1998) Included blocks (and blocks within blocks) in the Skaergaard intrusion: geologic relations and the origins of rhythmic modally graded layers. Geological Society of America Bulletin 110: 1398-1447

Karup-Møller S, Mackovicky E, Barnes S-J (2008) The metal-rich portions of the phase system Cu$\mathrm{Fe}-\mathrm{Pd}-\mathrm{S}$ at $1000{ }^{\circ} \mathrm{C}, 900{ }^{\circ} \mathrm{C}$ and $725{ }^{\circ} \mathrm{C}$ : implications for mineralization in the Skaergaard intrusion. Mineralogical Magazine 72: 941-951

Latypov R, Morse SA, Robins B, Wilson JR, Cawthorn RG, Tegner C, Holness MB, Lesher CE, Barnes SJ, O'Driscoll B, Veksler IV, Higgins MD, Wilson AH, Namur O, Chistyakova S, Naslund HR, Thy P (2015). Fundamentally flawed: A discussion of 'Of some fundamentals of igneous petrology' by Bruce D. Marsh, Contributions to Mineralogy and Petrology. Contributions to Mineralogy and Petrology 166(3): 665-690

*Maier WD, Hanski E (2017) Layered mafic-ultramafic intrusions of Fennoscandia: mineral prospectivity in contrasting tectonic settings. Elements (this issue)

Marks MAW, Markl G (2015) The Ilímaussaq Alkaline Complex, South Greenland. In: Charlier B, Namur O, Latypov R, Tegner C (Eds) Layered Intrusions. Springer Science, Netherlands pp 649692

*Mathez EA, Kinzler RJ (2017) Metasomatic chromitite seams in the Bushveld and Rum Intrusions. Elements (this issue)

McBirney AR, Noyes RM (1979) Crystallization and layering in the Skaergaard intrusion. Journal of Petrology 38: 487-554

McBirney AR, Boudreau AE, Marsh BD (2009) Comments on: 'Textural maturity of cumulates: a record of chamber filling, liquidus assemblage, cooling rate and large-scale convection in mafic layered intrusions' and 'A textural record of solidification and cooling in the Skaergaard Intrusion, East Greenland'. Journal of Petrology 50(1): 93-95

*Morse SA, Davidson JP, Tepley III FJ (2017) Plagioclase zonation as an archive for magmatic processes in layered intrusions. Elements (this issue)

Mungall JM, Naldrett AJ (2008) Ore deposits of the platinum-group elements. Elements 4: 253-258 
Mungall JE, Kamo SL, McQuade S (2016) U-Pb geochronology documents out-of-sequence emplacement of ultramafic layers in the Bushveld Igneous Complex of South Africa. Nature Communications 7: DOI: 10.1038/ncomms13385

Naldrett AJ (2004) Magmatic Sulfide Deposits: Geology, Geochemistry and Exploration. Springer, Berlin

O’Driscoll B, Ferré EC, Stevenson CTE, Magee C (2015) The significance of magnetic fabric in layered mafic-ultramafic intrusions. In: Charlier B, Namur O, Latypov R, Tegner C (Eds) Layered Intrusions. Springer Science, Netherlands pp 295-329

Parsons I (ed) (1987) Origins of Igneous Layering. Dordrecht: D. Reidel pp 663

Sparks RSJ, Huppert HE, Kerr CR, McKenzie DP, Tait SR (1985) Postcumulus processes in layered intrusions. Geological Magazine 122: 555-568

Wager LR, Brown GM, Wadsworth WJ (1960) Types of igneous cumulates. Journal of Petrology 1: 73-85

Wager LR, Brown GM (1968) Layered igneous rocks. Oliver and Boyd, London, pp 1-588 


\section{Figure 1}
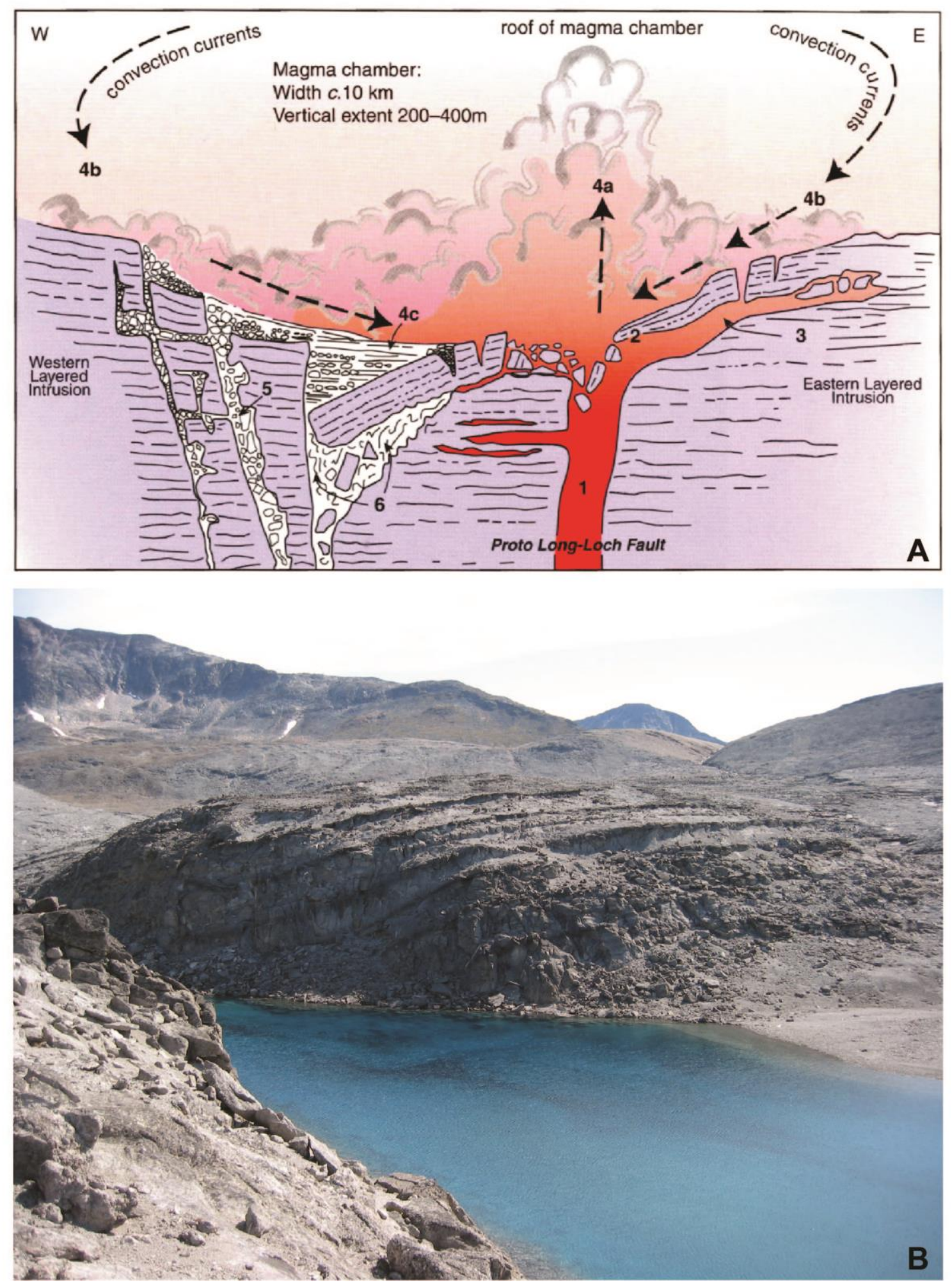

Figure 1. A. Schematic cartoon of a magma chamber, based on the Rum layered intrusion, NW Scotland, reproduced from Emeleus and Bell (2005) with the permission of the British Geological Survey. B. Gently dipping rhythmically layered nepheline syenites (kakortokites) in the upper part of the Ilímaussaq complex (South Greenland). Individual layers are on average $8 \mathrm{~m}$ thick and consist of a very amphibole-rich dark base that grades upwards into a much thicker alkali feldsparrich top. The photograph was taken at the Kringlerne plateau in the southern part of the complex. Photograph courtesy of Michael Marks (Tuebingen University, Germany). 


\section{Figure 2}

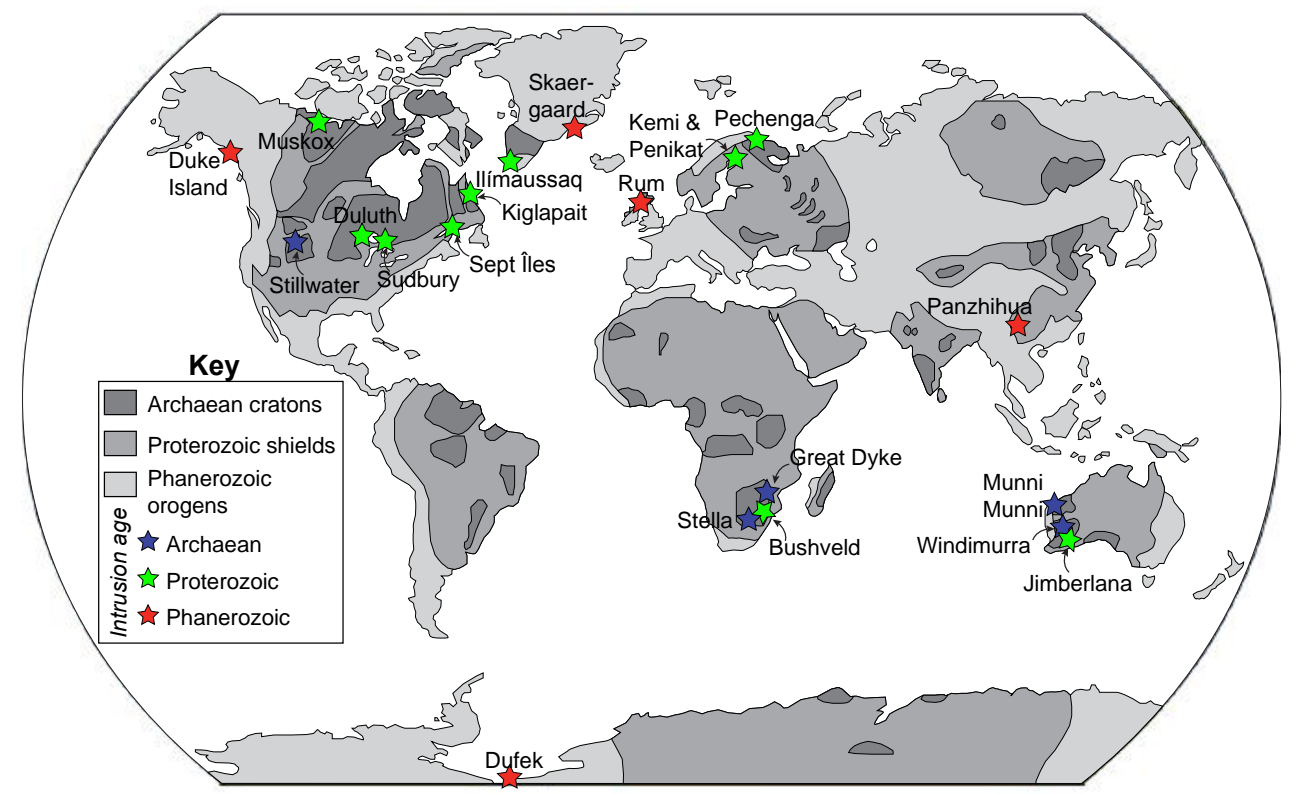

Figure 2. Sketch map of the world, showing the locations of some well-known layered intrusions. The intrusions are broadly sub-divided on the basis of timing of magma emplacement. 
Figure 3
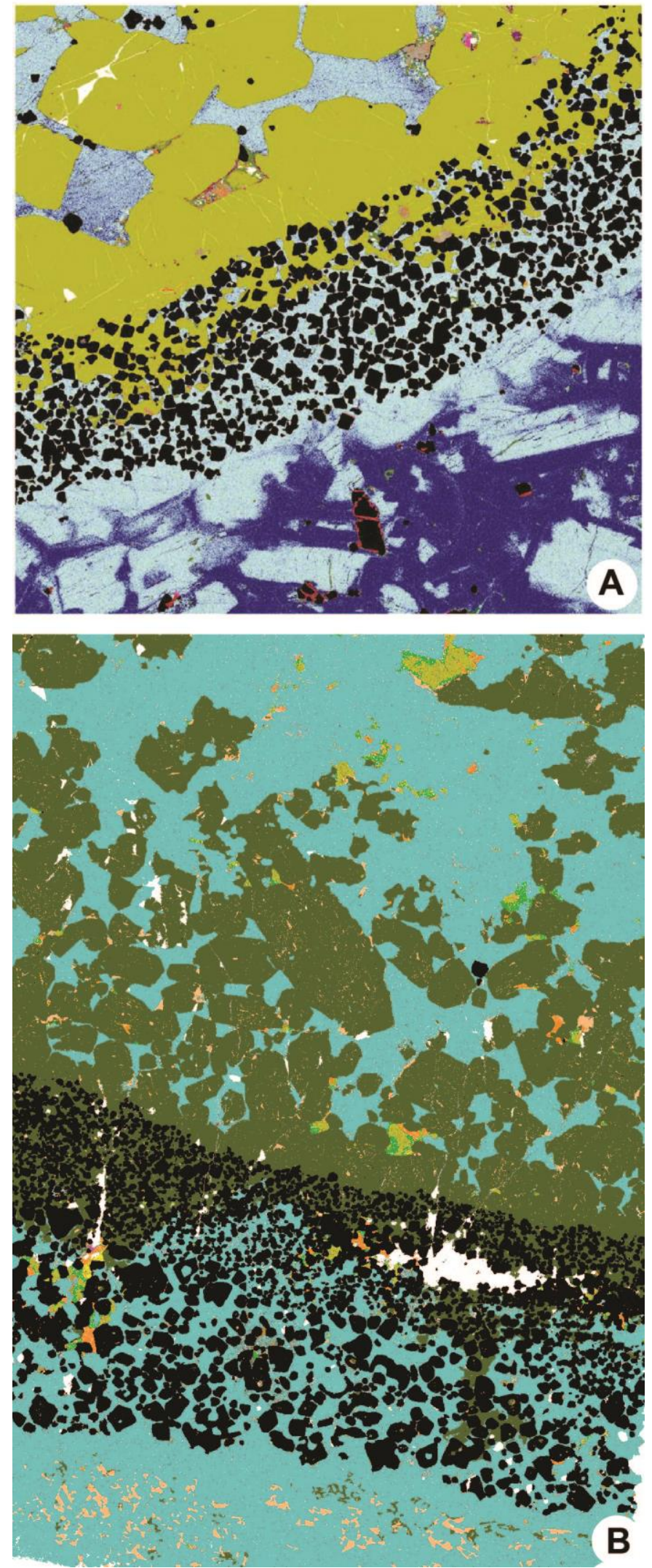

Figure 3. Mineral maps produced using the automated mineral identification software, QEMSCAN $^{\circledR}$. A. The Unit 7-8 boundary chromitite seam from the Rum Layered Suite. B. The lower chromitite of the Merensky Reef, Bushveld Complex. Both of these chromitite 'reefs' are highly enriched (ppm levels) in the PGE. One striking observation is that despite the great difference in intrusion size (two orders of magnitude difference in diameter), the chromitite seams are not dissimilar in thickness (i.e., $2 \mathrm{~mm}$ versus $10 \mathrm{~mm}$ for Rum and Bushveld, respectively). 


\section{Figure 4}

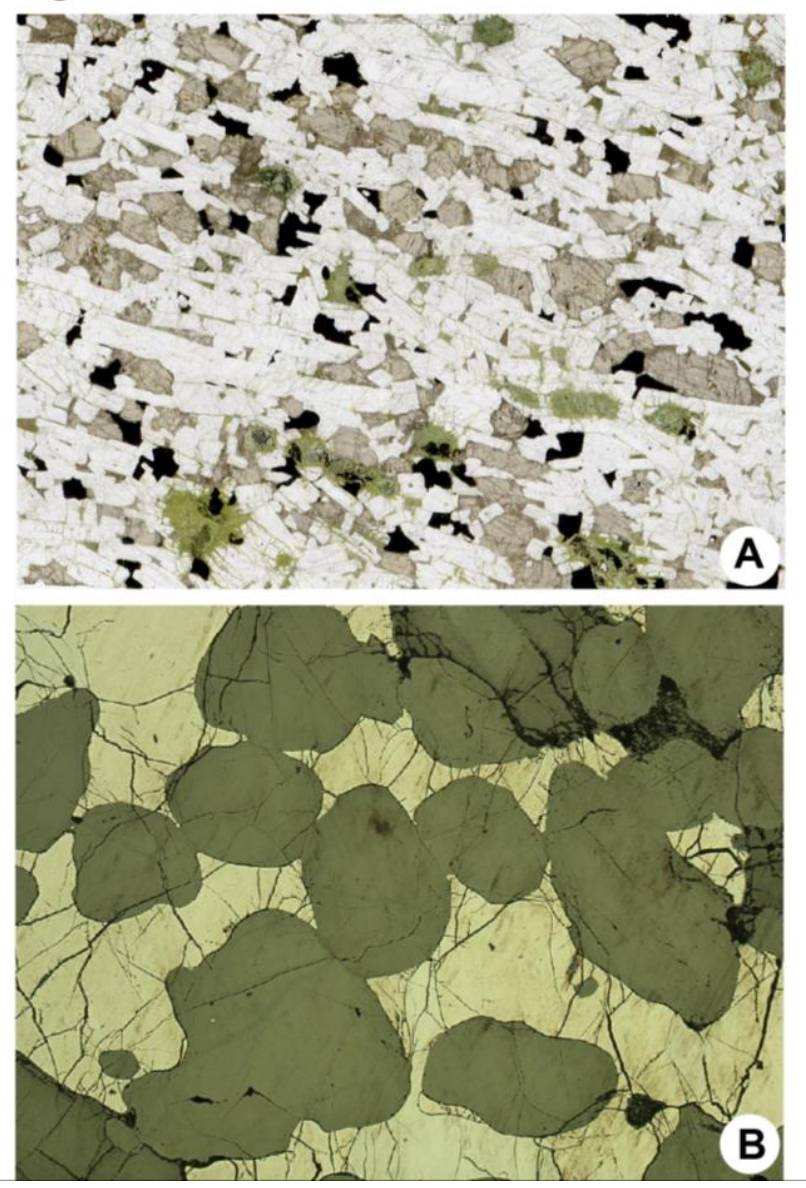

Figure 4. A. Transmitted light photomicrograph of a gabbroic adcumulate from the Druim Hain intrusion of the $\sim 60 \mathrm{Ma}$ Skye igneous centre, NW Scotland. Note the well-developed mineral planar foliation carried by the tabular plagioclase crystals. Clinopyroxene (brownish) and accessory magnetite (black) are also cumulus phases in this rock. Mineral fabrics such as this in cumulates have been the subject of much discussion in layered intrusions, and their formation has been attributed to a variety of processes, including crystal settling and density current action. B. Reflected light photomicrograph of an orthocumulate from the Druim Hain intrusion. The rounded cumulus crystals are clinopyroxene, and the bright phase occupying the intercumulus space is magnetite. See text for discussion. 


\section{Figure 5}
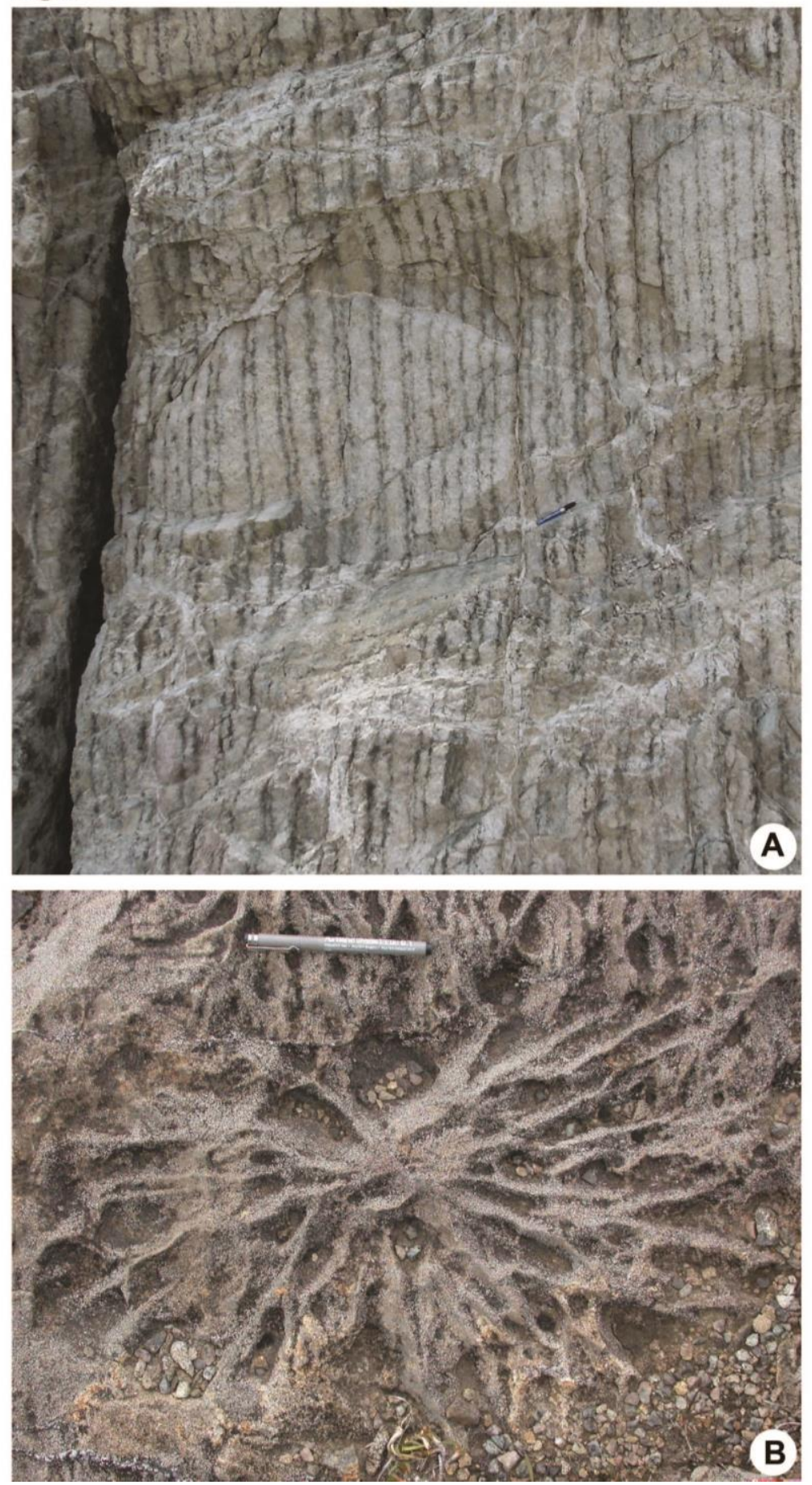

Figure 5. A. Field photograph of the 'inch-scale' layered anorthosites of the Lower Banded Zone of the Stillwater Complex, USA. These outcrops are one of the classic examples of in situ crystallization in layered intrusions, but have additionally been attributed to postcumulus crystallization in the cumulate pile (Boudreau 1995). The blue pen on the outcrop in the image centre is $\sim 15 \mathrm{~cm}$ long. B. Poikilo-macro-spherulite from the Central Intrusion of the Rum Layered Suite, NW Scotland. Each of the 'rays' in the stellate structure comprises $>1 \mathrm{~cm}$-sized plagioclase crystals, containing abundant mm-long tabular olivine chadacrysts. This texture is considered to have formed in situ from a parental magma oversaturated in plagioclase. The grey pen is $\sim 15 \mathrm{~cm}$ long. 


\section{Figure 6}
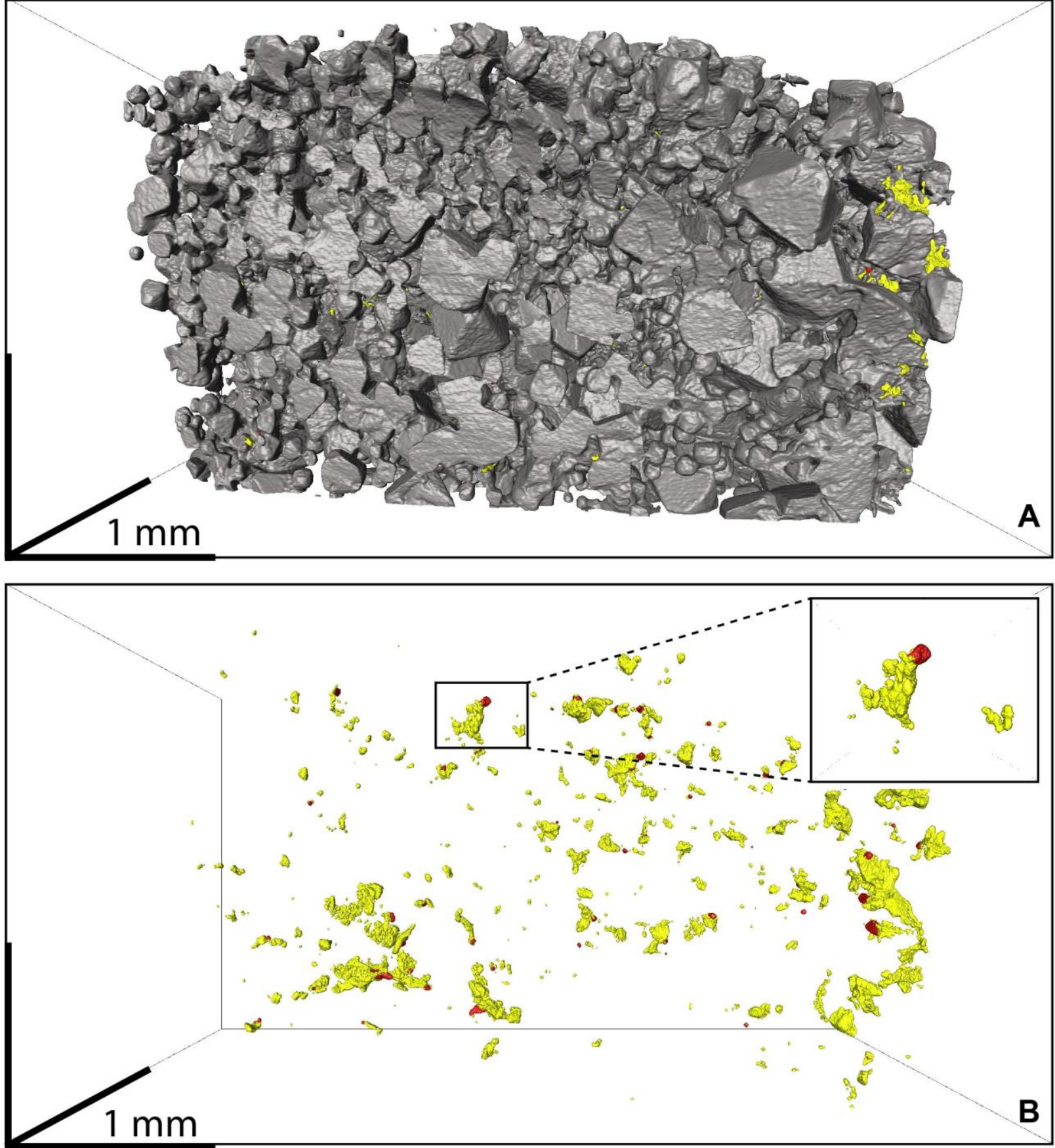

Figure 6. X-ray computed tomography scan of the upper chromitite seam of the Merensky Reef showing chromite in grey, sulphide in yellow and platinum-group minerals (PGM) in A. In B, the Cr-spinel has been stripped out, showing the 3D distribution of the sulphides and PGM. Note the close spatial association of the latter two phases. Image courtesy of Belinda Godel (CSIRO Mineral Resources, Perth). 
Glossary:

\section{Textural Terms}

Adcumulate - rock containing 93-100\% accumulated crystals in a fine-grained groundmass Mesocumulate - rock containing 85-95\% accumulated crystals in a fine-grained groundmass Orthocumulate - rock containing $75-85 \%$ accumulated crystals in a fine-grained groundmass

\section{Rock Names}

Anorthosite - cumulate rock containing more than $90 \%$ plagioclase

Allivalite intrusive rock containing equal proportions olivine and plagioclase

Ferrosyenite coarse-grained intrusive rock containing alkali feldspar and iron-rich minerals such as fayalite or hedenburgite

Gabbro - cumulate rock containing plagioclase and pyroxene (majority clinopyroxene)

Harzburgite - coarse-grained rock containing olivine and orthopyroxene, can be formed by crystal accumulation in a magma chamber or as a restitite during partial melting of the mantle

Norite - cumulate rock containing plagioclase and orthopyroxene

Orthopyroxenite - cumulate rock containing more than $90 \%$ orthopyroxenite

Picrite - $\quad$ high magnesium, low silica basaltic composition

Troctolite - cumulate rock containing plagioclase and olivine

Other

Cotectic - the temperature at which multiple crystals will co-crystallize from a magma of a given composition. E.g. the olivine-plagioclase cotectic

Incongruent melting - melting of a solid which results in the formation of a new solid of different composition plus a liquid

Liquidus - $\quad$ the temperature at which crystals will form from a magma of a given composition

Metasomatism - metamorphism by fluids, whether magmatic or hydrothermal

Solidus - $\quad$ the temperature at which a magma will be fully solidified

Reef - $\quad$ a rock layer containing enhanced base or precious metal mineralization with a distinctive texture and/or mineralogical composition

Macrorhythmic Unit - a repeating series of cumulate layers that alternate cyclically on a large scale $(0.5-5 \mathrm{~m})$. For example, a unit may consist of a layer of dunite, followed by troctolite, followed by anorthosite; which will then repeat in the next unit. 